\title{
IN-SERVICE TRAINING AND JOB PERFORMANCE OF LIBRARIANS IN UNIVERSITY LIBRARIES IN SOUTH SOUTH ZONE NIGERIA
}

E. N. NKEBEM

\begin{abstract}
There is a dearth of literature in the relationship between in-service training and job performance of librarians in Nigerian Universities in the South South zone of Nigeria. This study examines the relationship between in-service training and job performance of Librarians in University Libraries in Nigeria. A sample size of 172 Librarians was drawn from 11 University Libraries in the zone. One hypothesis was formulated to guide the study. The statistical analyses used were Pearson Product Moment Correlation (PPMC) and simple Regression Analysis. The result showed a significant relationship between in-service training and job performance of Librarians $(r=0.2757) ; r^{2},=0.076, d f=$ 170. Critical $r=0.195$. The result also showed that in-service training can significantly predict the job performance of librarians in Nigeria $(F=13.943 ; d f=1,170 ;$ critical $f=3.84 ; x=0.05)$. Recommendations are made based on these results.
\end{abstract}

KEY WORDS: In-service training; job performance; librarians; university libraries; relationship

\section{INTRODUCTION}

As a result of rapid transformation in the society due to the application of information technology, librarians had discovered the need for curricula reform in order to enhance professional services. It is pertinent for librarians and information scientists to develop the ability to provide varied information services for professional growth and development through inservice training. There is need for a librarian to have constant evaluation of himself in order to identify his area of weakness and make conscious effort for improvement by embarking on self study and practical exposure independent of an organization's contribution.

\section{PURPOSE OF THE STUDY:}

To examine the relationship between inservice training and job performance of librarians in University Libraries in the South South zone of Nigeria.

\section{HYPOTHESIS}

There is no significant relationship between In-service training and job performance of librarians in Nigerian Universities in the South South zone.

\section{LITERATURE REVIEW}

Librarians' needs for training has not been identified and provided for as an indispensable part of management function. Nwachukwu (1988) defined training as organizational effort aimed at helping an employee to acquire basic skills required for the efficient execution of the functions for which he was hired. Librarians benefit from continuing education provided by work environment albeit, subconsciously. A University library, for example, runs the risk of disorganizing its catalogue of a new recruit is given a free hand to catalogue and classify some of its materials without going through the tutelage of an experienced cataloguer. The new recruit has to be made to work alongside others in the workroom to enable him to acquire practical knowledge of all the theories he has learnt through his formal education. This experience is the 'on-the-job' or continuing education necessary for the recruit to skillfully handle

E. N. Ekebem, Cross River University of Technology Library, Calabar , NIgeria 
various activities (Agaja, 1999). Cooper and Payne (1980) indicated in their study that learning on-the-job exposes employees to new experiences and techniques of performing the task. According to the authors, this is a more efficient way of motivating workers and getting their co-operation, support and high performance for the realization of institutional goals.

As part of their manpower development strategies, Nigerian Universities usually make provision for retraining of all categories of staff in their annual budgets. Librarians in Nigerian University Libraries benefit from the provision as they sometimes receive training for higher degrees under their Universities' in service training programmes S. Aitken, (2004) defines inservice training as the ongoing training of practicing professionals, which is typically arranged by the boards that employ them. He reported that the Education Review Office (ERO) of New Zealand carried out a case study of inservice training in schools nationally. The study was based on direct observation and discussion between review officers and stakeholders, documentary materials especially self-review information supplied by the schools and the perspective provided by earlier reports on the schools. The study aimed at examining how well retraining were currently managed in order to inform government policies about in service training; and to provide information about good practice that will assist schools to use in-service training effectively. The reports indicated that inservice training has many objectives, which include specific learning activities tailored to the development needs of teachers and schools; as well as running of nation-wide courses funded by the Ministry of Education to equip teachers to deal with curriculum and other changes. Their findings include the following facts; effective inservice training enhances teacher performance and this in turn brings about improvements in students' achievement; in-service training of teachers is the key mechanism to equip schools to respond to many challenges; demographic factors have significant impact on in-service training requirements; in- service is necessary to ensure that teachers skills and capabilities continue to meet the changing requirements placed upon them; in-service training, unlike preemployment training, can affect all practicing teachers, and thus has a wider and more immediate impact on the effectiveness on the teaching work-force as a whole. One can easily observe the relationship between school environment and university library environment.
In which case what is applicable to teachers' inservice training is also applicable to librarians in University Libraries.

The result suggests that teachers who receive in-service training are likely to show better output towards their job than those who do not receive in-service training and that the more a teacher gets more experience in terms of new skills and knowledge acquired, the likelihood of such teacher showing a positive and favorable job performance. One aspect, however, is to make professional continuing education for librarians an integral part of university library development and other is to pursue concerted efforts aimed at its realization. It is in recognition of this observation that Aboyade (1976) recommends that in order to promote continuing education of their staff, university librarians should take certain actions such as:

(a) arranging to have regular professional meetings or training sessions within their libraries;

(b) Sponsoring their staff for relevant courses whenever they are available;

(c) Granting periodic study leaves;

(d) Rewarding those who undertake further studies with promotion or an increment in salary, especially if they display superior or improved skills as a result of some further education.

Agaja (1999) posits that librarianship is being gradually accepted as a dynamic profession whose members should constantly seek for new and better ways of information acquisition, storage and dissemination through planned interactions among professional colleagues, as well as participation in short and long term courses in the country. The author enumerated further those refresher courses such as, on-the job training, conferences, workshops, seminars or in-service training as means of training for efficient development. These had buttressed what Adelabu (1974) had already said on this. It can therefore be deduced from the fore-going postulations that no matter the nature of a course an individual embarks upon, there is always experience gained for productivity.

\section{METHODOLOGY}

The ex-post facto design was used for the study. The area of the study comprises all the Universities in the South-South zone of Nigeria. One hundred and seventy two (172) Librarians in the eleven accredited Universities 
Libraries were used for the study. A researcher designed questionnaire with four points Likert's scale was used for the collection of data. Data collected were analyzed and interpreted as shown below:

\section{HYPOTHESIS}

This hypothesis stated in the null form that there is no significant relationship between in-service training and librarians' job performance.

To test this hypothesis, Pearson Product Moment Correlation analysis was done and the correlation coefficient tested for significance using the associated probability. The table below presents a summary of the results.

Results of correlation between librarians' performance and their in-service training

\begin{tabular}{|c|c|c|c|}
\hline & \multicolumn{3}{|c|}{ Descriptive $\quad$ Statistics } \\
\hline Variable & Mean & & Std. Dev \\
\hline In-Service training & 13.34 & & 2.21 \\
\hline Librarians' Performance & 18.78 & & 3.38 \\
\hline Statistics & Variable & $\begin{array}{l}\text { In-Service } \\
\text { training }\end{array}$ & Librarians' Performance \\
\hline Pearson Correlation & $\begin{array}{l}\text { In-Service training } \\
\text { Librarians } \\
\text { Performance }\end{array}$ & $\begin{array}{l}1.000 \\
0.275^{\star}\end{array}$ & $\begin{array}{l}0.275^{*} \\
1.000\end{array}$ \\
\hline Sig. (2 tailed) & $\begin{array}{l}\text { In-Service training } \\
\text { Librarians' } \\
\text { Performance }\end{array}$ & 0.000 & 0.000 \\
\hline $\begin{array}{l}\text { Sums of Squares } \\
\text { And }\end{array}$ & In-Service training & 834.442 & 351.477 \\
\hline Cross Product & $\begin{array}{l}\text { Librarians } \\
\text { performance }\end{array}$ & 351.477 & 1953.041 \\
\hline Covariance & $\begin{array}{l}\text { In-Service training } \\
\text { Librarians } \\
\text { Performance }\end{array}$ & $\begin{array}{l}4.880 \\
2.055\end{array}$ & $\begin{array}{l}2.055 \\
11.421\end{array}$ \\
\hline $\mathrm{N}$ & $\begin{array}{l}\text { In-Service training } \\
\text { Librarians' } \\
\text { Performance }\end{array}$ & $\begin{array}{l}172 \\
172\end{array}$ & $\begin{array}{l}172 \\
172\end{array}$ \\
\hline
\end{tabular}

\section{*Significant at 00.5 level}

\section{DATA ANALYSIS}

From the table, the correlation coefficient of 0275 given that the sample size is 172 has an associated probability (0.000) less than the chosen level of significance. Thus the null hypothesis was rejected while the alternative was retained. The means that there is a significance relationship between Librarians' performance and their in-service training. Further analysis was done to find out if Librarians' performance could be predicted from provision of in-service training. Simple linear regression analysis was done and F-ratio test employed to test the significance of the prediction. The results are presented in the table. 


\section{ANOVA Presentation of the regression of Librarians'}

Performance on In-Service training.

\begin{tabular}{lllll} 
Source of Variation & SS & df & ms & F \\
Residual & 1804.995 & 170 & 10.618 \\
Total & 1953.041 & 171 & \\
\hline
\end{tabular}

$a=13.167 \pm 1.525 ; b=0.421 \pm 0.113 ; r^{2}=0.076$

*Significant at 0.05 level, $\mathrm{df}=1,170$

Predictors (constant), In-service training

Dependant variable: Librarians' Performance

From the table, the calculated F-Value (13.913) is greater than the critical F-value (3.84). On this basis, the null hypothesis was rejected in favour of the alternative. This means that Librarians' performance depend significantly on the provision of in-service training. The prediction equation obtained is:

\begin{tabular}{|c|c|c|c|}
\hline & $\mathrm{y}$ & $=$ & $13.167=0.421^{*}$ \\
\hline Where & $\mathrm{y}$ & $=$ & Librarians' performance \\
\hline & $\mathrm{x}$ & $=$ & Level of in-service training \\
\hline
\end{tabular}

The obtained $r^{2}$ of 0.076 is an indication that about $7.6 \%$ of the total variation in Librarians' performance is responsible for the variation in the level of in-service training.

\section{DISCUSSION}

The analysis revealed that there was significant relationship between in-service training and job performance of librarians in university libraries as the calculated $r$ - value of 0.275 given that the sample size was 172 has an associated probability of 0.000 less than, the chosen level of significance 0.05 . This means that when librarians undertake in-service training, benefit therein will help them to update their knowledge which in turn help to improve their job performance in their various libraries. When they do not attend in-service training, their performance in work places stand to be low and of course this will result in low productivity.

This finding is in agreement with Agaja's (1999) finding which revealed that librarianship is gradually accepted as a dynamic profession whose members should constantly seek for new and better ways of information acquisition, storage and dissemination through planned interactions among professional colleagues, as well as participation in short and long term training in the country. The improvement of skills entails improvement of job performance and productivity. In-service training is a form of training. It falls under formal training which any good educational institution must set to embark upon. However, in university libraries, it may expose librarians to skill acquisition for efficient work and productivity. Hence correlation coefficient 0.275 is not too close to +1 . Therefore, the significant relationship is not strongly positive. From the finding of regression analysis $F$ - value (13.943) is greater than the critical F-value (3.84). This revealed that the null hypothesis was rejected in favour of the alternative hypothesis, which means that Librarians' job performance depend on number of in-service they embark upon.

\section{CONCLUSION}

Librarianship today has gone beyond the rudimentary process of the ancient days into the Information Communication Technology (ICT) connectivity. It is now looked at as library without borders. This talks about globalization in library and information technology. A librarian who wants to remain in vogue must vent out to develop himself. This entails conscious and deliberate effort. However, this might seem to be a task but at the end it is always a task that worth it. This study should be seen as encouragement to all today's librarians in Nigerian Universities. 


\section{REFERENCES}

Agaja, J. A., 1999. Professional Continuing Education for Librarians in Nigerian University Libraries: Opportunities, problems and prospects. Annals of Library Science and Documentation. 46, (1): $19-24$.

Aitken, J. E., 2004. In-service training for teachers in New Zealand Schools What's New Publications. North American Association of Educational Negotiators (NAEN), 15, (1): p. 5.

Aboyade, B. O., 1976. Promoting Continuing Education for Librarianship in Nigeria. Nigerian Libraries, 12, (2 and 3): $21-22$.
Agaja, J. A., 1999. Op cit 46

Adelabu, A., 1974. Professional Staff of tomorrow's future in African University Libraries: Some Postulated Review. International Library Review, 6, (3): 308.

Cooper-Smith, C. C. and Payne R., 1980. Stress at work. New York. John Wiley and sons.

Nwachukwu, C., 1988. Management: Theory and Practice, Onitsha, Africana FebPublishers. 
